\title{
The impact of public private partnership in the role of coffee farmers' cooperative societies in Kenya
}

\author{
Harrison Mugo ${ }^{1 \star} \bullet$ Hudson Lubabali ${ }^{1}$ Beatrice Salasya ${ }^{2}$ \\ ${ }^{1}$ Kenya Agricultural and Livestock Research Organization - Coffee Research Institute (KALRO- CRI), P.O Box 4 - 00232, Ruiru, \\ Kenya. \\ ${ }^{2}$ Kenya Agricultural and Livestock Research Organization, P.O Box 57811 -00200, Nairobi, Kenya. \\ *Corresponding author. E-mail: mugohmu@yahoo.com
}

Accepted $27^{\text {th }}$ November, 2019.

\begin{abstract}
Coffee production in Kenya plays a key role as source of foreign exchange earnings. It is produced by both small and large-scale farmers in 32 coffee growing Counties. The national production is constrained by shortage of seedlings of improved coffee varieties (Ruiru 11 and Batian) among other factors. Coffee Research Institute partnered with Cooperative Societies through Public Private Partnership (PPP) to produce and supply seedlings of the improved varieties to the farmers. Eight (8) coffee Farmers Cooperative Societies (FCSs) under PPP in eight (8) coffee growing Counties were surveyed to establish the impact the partnerships had in their role. The societies surveyed (100\%) indicated that their staff were capacity built during the partnership. The coffee nurseries in the Cooperatives were expanded where the annual mean coffee seedlings produced per society increased by $367 \%$ from 15,000 to 70,000 . The revenue generated per society increased by $400 \%$ from average of Kshs 200,000 to 1,000,000 from sales of seedlings. The average membership per society increased by $15 \%$ from 2444 to 2807 members. On average, the coffee cherry delivered per society increased by $25 \%$ from 228 to 286 metric tons. Job creation was also realized where on average, nine (9) employees per society were engaged to provide services in the coffee nurseries. Evidently, this Public Private Partnership model under coffee enterprise, positively impacted on the role of the Cooperatives. A model that can be applied on other enterprises to improve the livelihood of the community.
\end{abstract}

Keywords: Coffee, cooperative societies, public private partnership, membership, livelihood.

\section{INTRODUCTION}

Coffee is the most important agricultural commodity in the global trade and the second most valuable commodity after petroleum. Among the beverages, coffee is the most widely used despite being a natural source of caffeine used in beverages (cola), pharmaceuticals and cosmetics (Mazzafera, 2012). It is estimated that more than 125 million people globally derives their livelihoods from the coffee industry (Fair-trade and Coffee, 2012).

Coffee production in Kenya plays a key role as source of foreign exchange earnings to the Country. It is produced by both small and large scale coffee farmers in
32 Counties (Figure 1). The small scale farmers belong to Farmers Co-operative Societies who produce about $80 \%$ and the large scale farmers (Estates) produce about 20\% of the total national coffee production (United States Agency for International Development, 2010).

A cooperative is collectively owned firm, established to support the economic performance of its members. According to the International Cooperative Alliance (ICA), a co-operative is defined as an autonomous association of persons united voluntarily to meet their common economic, social, and cultural needs and aspirations 


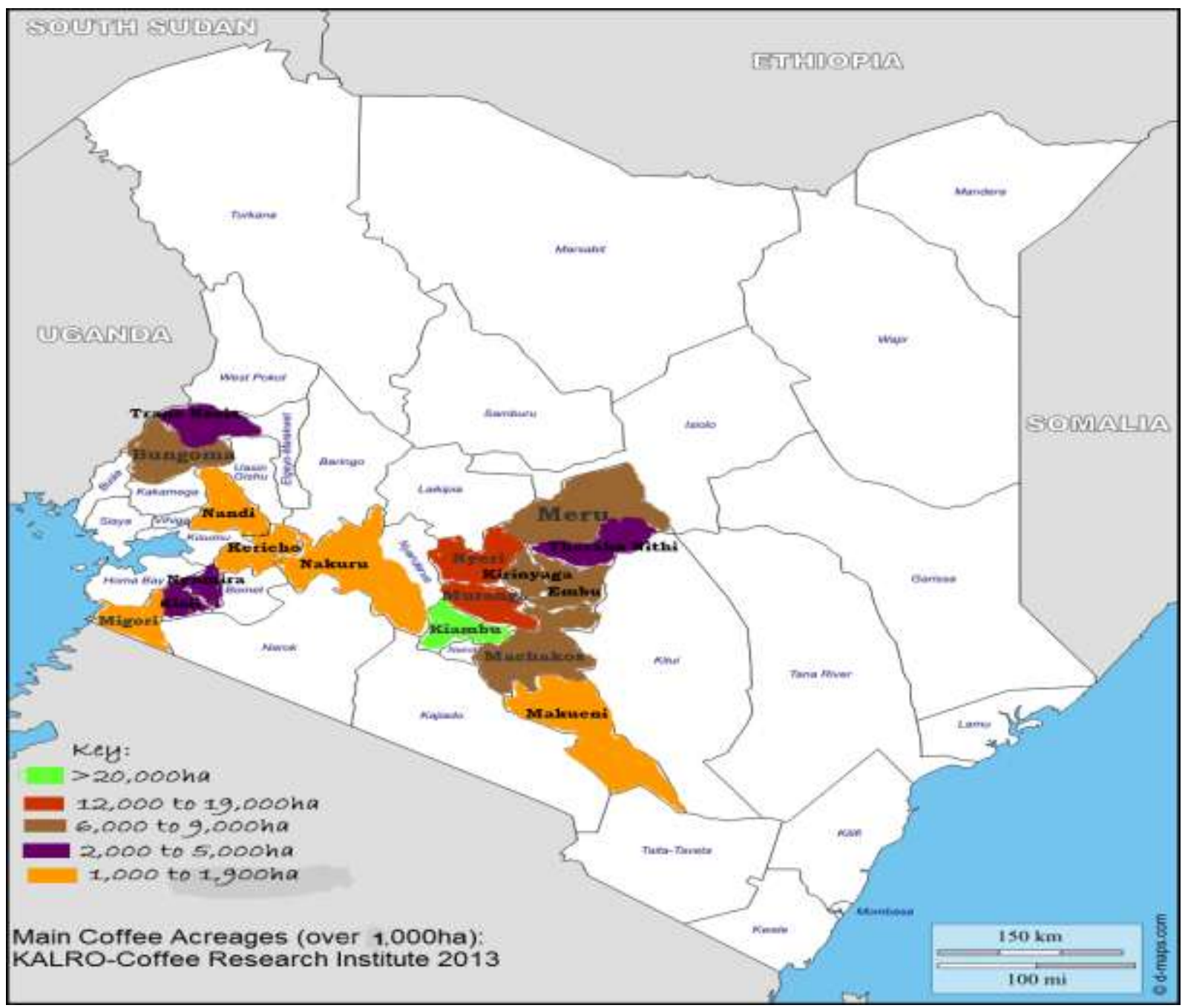

Figure 1. Main coffee growing counties in Kenya.

through a jointly owned and democratically-controlled enterprise (International Cooperative Alliance, 2007). Coffee Cooperatives faces many constraints such as inadequate basic infrastructure (water, electricity, roads, etc.), lack of human, material and financial resources, and low level of participation of members in the cooperative organization and management (Ministry of Agriculture and Animal Resources, 2004)

The Cooperative Societies despite the constraints they face plays major role that assist the farmers to manage and market their coffee locally and internationally (Kamau, 2014). In Ethiopia for instance, several coffee farmers' cooperatives exist that support farmers who have no negotiating power in the global economy. They play an effective role in supporting coffee farmers by supplying the price information, capital, transportation and negotiations in the international market. They are also known to provide higher profits to coffee farmers when compared with private traders. However, their actual volume of purchase is limited due to financial constraints (Yuka, 2007). In Kenya, the Cooperative movement started back in 1963 (Aksoy, 2012) and presently there are 525 Cooperatives in the Country (Kimemia, 2018). Their role includes provision of quality coffee seedlings, supply of farm inputs, training and offering advisory services to farmers, and support in marketing of farmers coffee among others.

The Coffee Traders Association (2015) estimated that in Kenya, coffee occupies about 104,000 hectares equal to $3 \%$ of the total available agricultural land. This has increased to 114,500 hectares (Akuma, 2018; International Coffee Organization, 2019). The national annual coffee production in the Country is estimated to vary between 39,000 to 49,000 metric tons (Akuma, 2018 ) in the last five years. This is a noted decline of between 62 to $70 \%$ from a peak of 130,000 tonnes of clean coffee in $1987 / 88$. The decline is attributed to high cost of coffee production in the country due to increases in the cost of purchased farm inputs, electricity and labour supply, and management of coffee diseases. 


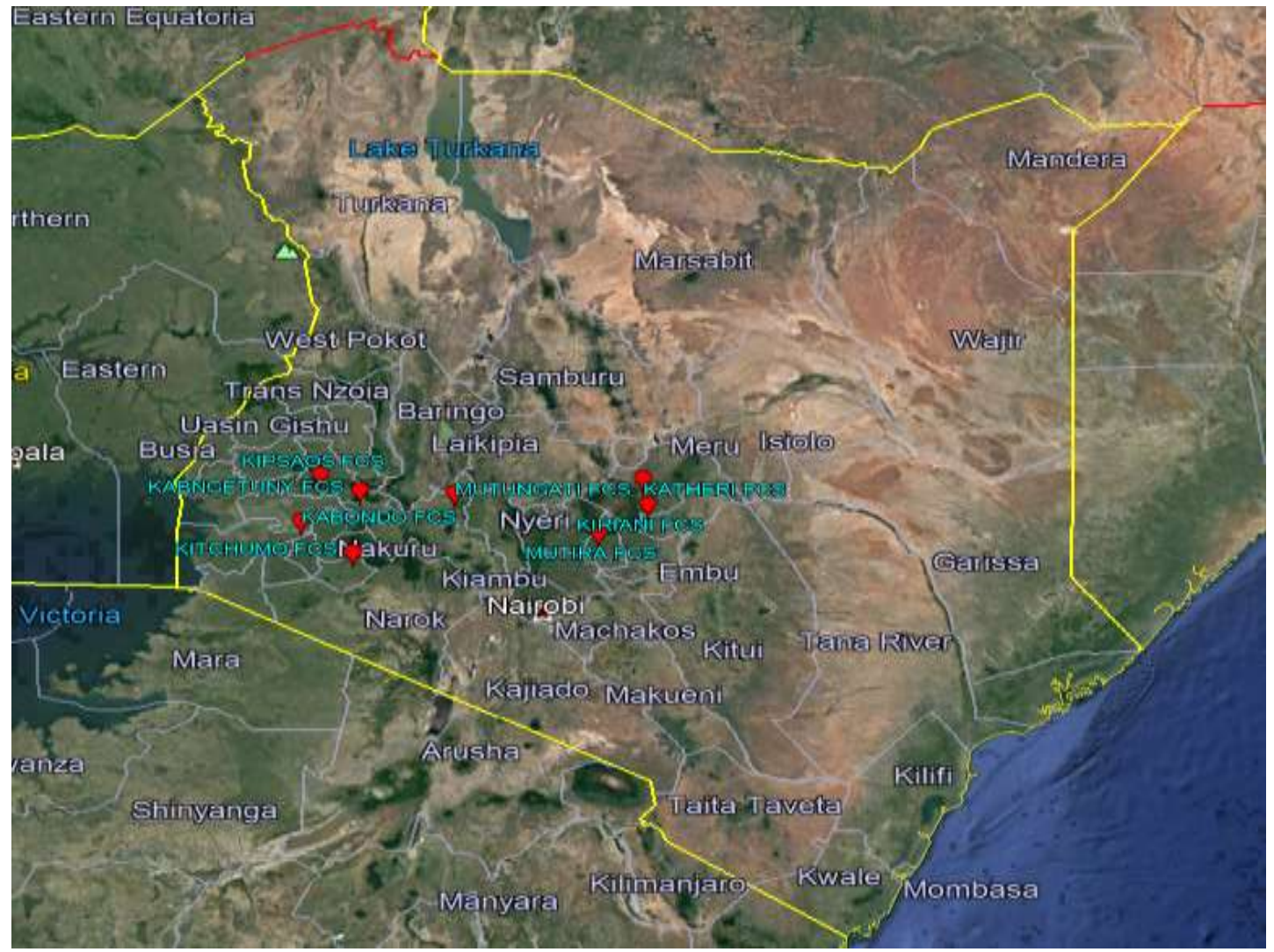

Figure 2. Cooperative societies where the study was carried out.

The coffee diseases, mainly the Coffee Berry Disease (CBD) and Coffee Leaf Rust (CLR) are the major coffee diseases in Kenya. Their management is a key cost centre estimated to account for $30-35 \%$ of total coffee production costs (Van der Vosen and Walyaro, 2009). The two diseases if not managed can cause a crop loss of up to $80 \%$ (Van der Vosen and Walyaro, 2009). The long-term solution for control of CBD and CRL in Kenya is the adoption of disease resistant coffee varieties (Ruiru II and Batian) developed by Kenya Agricultural and Livestock Research Organization- Coffee Research Institute (KALRO-CRI) which is the only Institution mandated to carry out research and development on coffee in country. However, there has been high demand and shortage of the planting materials of these improved coffee varieties. As a result, a Coffee Productivity Project (CPP) was established to address the shortage and the demand of the planting materials through a collaboration between $\mathrm{CRI}$ and Coffee Cooperatives as private nursery operators. The project was jointly funded through a grant by European Development Fund (EDF) (88\%) under Kenya Rural Development Programme (KRDP) and the Government of Kenya (12\%) through KALRO - CRI. The aim of the project was to expand the nursery capacities of Cooperatives (to produce seedlings of Ruiru 11 and Batian) as well as expand area under coffee production by the smallholders coffee farmers in the Country through
Public Private Partnership (PPP). The KALRO-CRI as the implementing agent contributed $88 \%$ of the funding, while the Cooperatives gave $12 \%$ through the PPP model.

The Coffee Cooperatives in Kenya fails to play their role because of the major challenges such as lack of human, material and financial resources. The Coffee Productivity Project provided the financial resources that aimed to improve the performance of service deliveries of the Coopertaives to the farmers. Hence this paper outline the Impact of Public Private Partnership in the role of coffee Farmers' Cooperative Societies in Kenya.

\section{MATERIALS AND METHODS}

\section{Study sites}

Coffee in Kenya is grown in two regions, East and West of Rift Valley (Figure 1). The KARLO - CRI through Public Private Partnerships, partnered with 19 Coffee Farmers Cooperative Societies (FCSs) in 11 coffee growing Counties for period of four (4) years. Eight (8) out of the 19 Cooperatives from eight (8) coffee growing Counties were purposely selected for an in-depth study. The Cooperatives studied according to their location in different Counties are shown in Figure 2. Mutungati FCS, Mutira FCS, Kiriani FCS and Katheri FCS from Nakuru, 
Kirinyaga, Tharaka Nithi and Meru Counties, respectively represented the East of Rift valley. While Kitchumo FCS, Kabondo FCS, Kapsaos FCS and Kabngetuny FCS from Bomet, Homa Bay, Nandi and Kericho counties respectively represented the West of Rift Valley.

\section{Sampling procedure and sample size}

Purposive sampling was used to select the eight Cooperative Societies (four from traditional coffee growing areas/East of Rift Valley and four from new growing areas/West of Rift Valley). A total of eight (8) secretary managers / Chief Executive Officers from the eight FCSs were interviewed during the survey using a formal questionnaire. The questionnaire had several parts that included the capacity building and productivity of staff employed by the Coopertaives, coffee nurseries and seedlings production, revenue generation from sale of seedlings, coffee cherry delivered to the Cooperative, membership in societies, coffee acreage of farmers affiliated to the Cooperatives and employment opportunities created to the community.

\section{Data collection}

Data was collected by trained enumerators using the questionnaire that was uploaded in Open Data Kit (ODK) mounted in smart phones. The responses from Secretay Managers were entered into the smart phones and electronically transmitted to a central server after verification for accuracy by each County data collection supervisor.

\section{Data analysis}

Captured data were exported to an excel spreadsheet in a comma-separated value (CSV) format after cleaning, validation and collation for accuracy and consistency. The excel data files were eventually exported to IBM SPSS software version 15 for analysis. Quantitative data analysis mainly on means was done based on the key variables in the data set. The results were presented in form of tables, graphs and charts.

\section{RESULTS AND DISCUSSION}

\section{Distribution of the sampled cooperative societies}

The survey sampled eight (8) Cooperative Societies that were distributed in coffee growing areas in Kenya (Figure 2). Four (4) were from East of Rift Valley where coffee is traditionally grown. The rest were from West of Rift Valley where regarded as new coffee growing areas.

\section{The project (CPP) support and impact on the role of FCSs}

The coffee Farmes' Cooperative Societies benefitted from the project by receiving funds of between Euro 25,000 to 37,500 each. They utilized the funds in capacity building of the staff, seedlings production, improvement of infrastructure and office equipment (Table 1). This impacted in several areas that included staff training and productivity, coffee seedlings production, revenue generation, and increased registered membership and cherry delivery to the societies. There was also employment opportunities realized in the Cooperatives.

Among the Cooperative Societies surveyed, 100\% used the funding to capacity built their staff and in seedlings production (Table 1). This was followed by the improved infrastructure (50\%). Other activities (62.5\%) supported through the project included temporary employment of unskilled and semi-skilled staff in coffee nurseries, establishment of Clonal gardens and Demonstration plots, and payment of loans (Table 1).

\section{Training and productivity of staff}

Management and operations of coffee Cooperatives faces various governance challenges. A major challenge was engaging of staff who lack the necessary skills and knowledge on management and operation of the societies leading to poor delivery of services to farmers. According to Ellis (2005), management skills by staff employed by Cooperatives is critical as this determine the performance of coffee Cooperatives. Kamau (2014) established that to improve the performace of the Coopertaives, management skills was one of the factors that influenced the performance. Prior to project implementation, the managerial and other support staff from Cooperatives were trained. This ensured the project was efficiently managed and positive impact attained. During the survey, the respondents (Chief Executive Officers or Secretary Managers) (100\%) indicated that there was training of staff at managerial level on financial management, procurement processes, business planning and reporting. Six Cooperatives (75\%) had each one managerial level staff trained while two $(25 \%)$ had at least two staff trained in the same level (Table 2). Fifty percent $(50 \%)$ of the Cooperatives had each two coffee nursery attendants trained on nursery management, coffee grafting/top working, nursery diversification and coffee agronomic practices. The others $(50 \%)$ had three or four nursery attedants trained (Table 2 ).

All the respondents (100\%) pointed out that there were visible positive changes in the way they managed and operated their respective Cooperatives after being trained. Similarly, $100 \%$ of them indicated that the training was useful to the Cooperatives/institutions they worked for. Following the training, the Secretary 
Table 1. How the funds were used.

\begin{tabular}{lc}
\hline Use & Response (\%) \\
\hline Capacity building for staff & 100 \\
Seedlings production & 100 \\
Improved infrastructure (water, electricity supply) & 50 \\
Office equipment & 37.5 \\
Others & 62.5 \\
\hline
\end{tabular}

Table 2. Number and cadre of staff trained.

\begin{tabular}{lc}
\hline Staff trained & Response (\%) \\
\hline Managerial (1 staff) & 75 \\
Managerial ( $>1$ staff) & 25 \\
Nursery attendant (1 staff) & 50 \\
Nursery attendants $(>1$ staff) & 50 \\
\hline
\end{tabular}

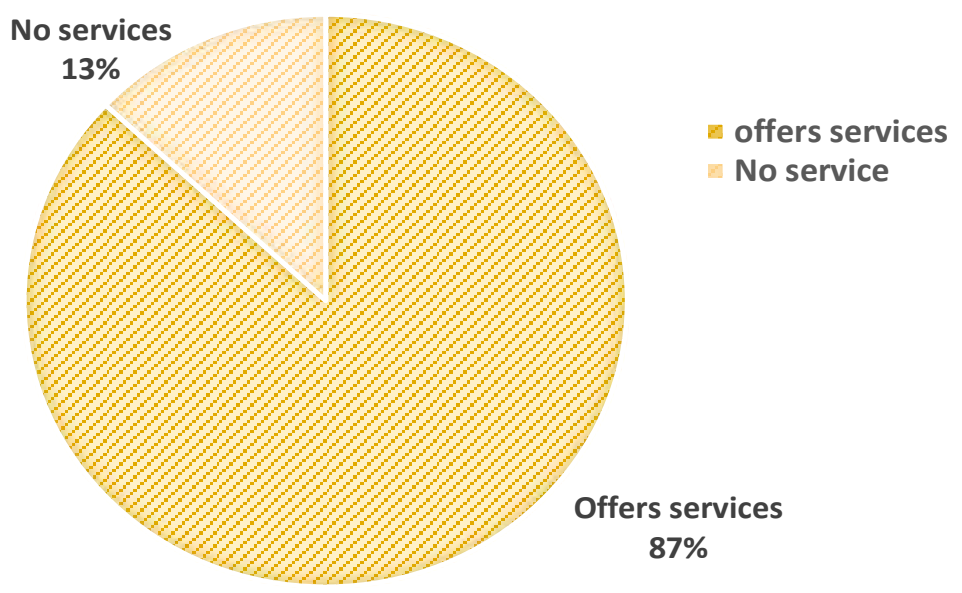

Figure 3. Percentage of cooperatives offering extension services to farmers.

managers were able to efficiently run the project. While the nursery attendants were able to manage the coffee nurseries by raising and supplying quality coffee seedlings to their affiliated cooperative members and other farmers. They also assisted the coffee farmers with traditional coffee varieties to convert them to Ruiru 11 following the knowledge they acquired on coffee grafting/top working.

The training of nursery attendants on coffee husbandry (establishment, pests management, soil nutrition, weeding, pruning and processing) provided key opportunities in offering various extension services to their affiliated farmers. The services aimed to impart knowledge to farmers and improve their farming hence increase in coffee production. Kamau (2014) established that training of farmers was importatnt as this improved their knowledge in farming as well as increased coffee production. Eighty seven percent $(87 \%)$ of the societies offered extension services. These included advisory services, training on coffee husbandry and information on grafting/top working. Only one (12.5\%) Society indicated that it never offered such services to its farmers (Figure 3 ) as the staff who were trained left the employment. Sevety five percent $(75 \%)$ offered atleast more than one type of extension services (Table 3). Training on coffee husbandry (75\%) and Advisory services (62.5\%) on coffee agronomic practices were the most common services offered by the cooperatives to their farmers. Other services farmers benefitted from included advisory on climate change and financial management, training on HIV/AIDS and distribution of seedlings.

\section{Production of coffee seedlings and revenue generation}

Production and supply of seedlings of the improved coffee varieties to the farmers was a major challenge to 
Table 3. Various extension services offered by cooperatives to the farmers.

\begin{tabular}{lc}
\hline Extension services & Response (\%) \\
\hline No services & 12.5 \\
Advisory services & 12.5 \\
Advisory services + Training on coffee husbandry & 12.5 \\
Advisory services + Training on coffee husbandry + Others & 25.0 \\
Advisory services + Training on coffee husbandry + Information on grafting/top working & 12.5 \\
Training on coffee husbandry + Others & 25.0 \\
\hline
\end{tabular}

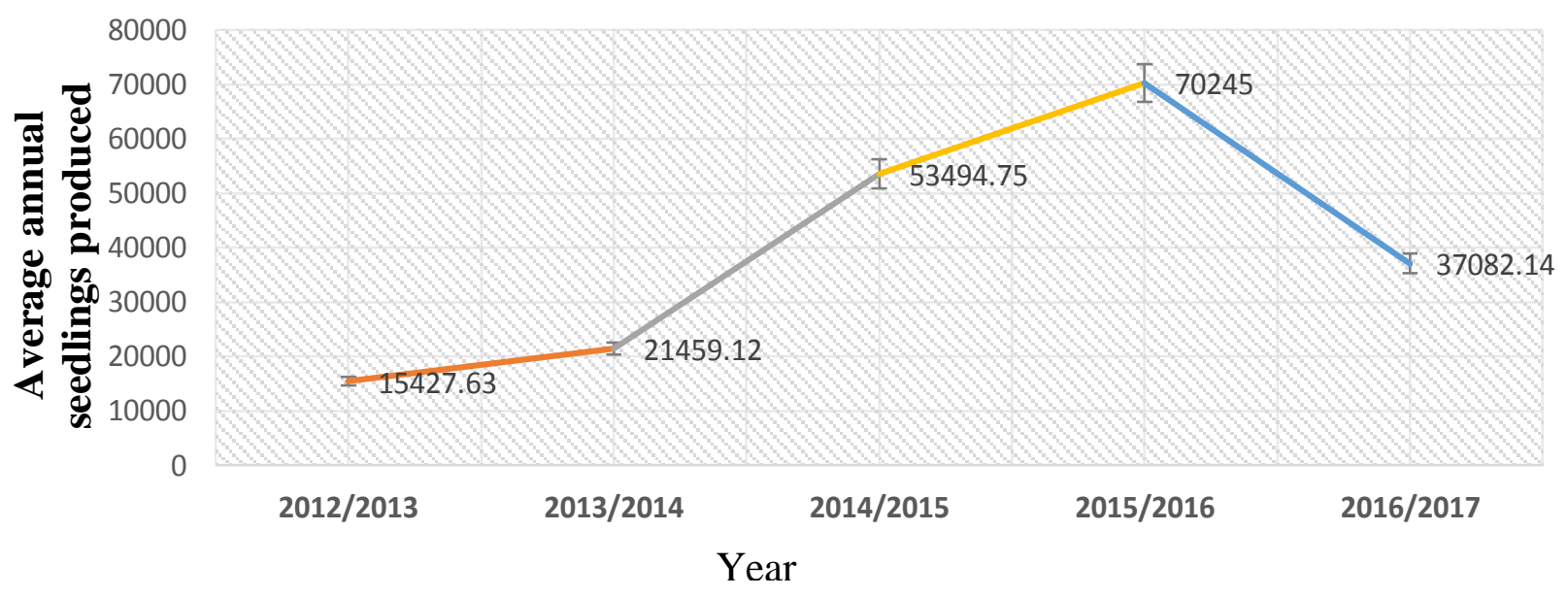

Figure 4. Average annual seedlings production per FCS.

the Cooperatives for lack of necessary infrastructures, and skills and knowledge in their areas of operations. The support of the Cooperatives through PPP facilitated in constructing coffee nursery structures and their associated facilities. In addition, staff to manage the nurseries were trained at Coffee Research Institute. These resulted into improved production and sales of seedlings as well as the revenue generation by the Cooperatives. The Cooperatives also managed to meet the demand of seedlings by the farmers.

Prior to project commencement in year 2013/2014, most of the Cooperatives produced no seedlings in years $2012 / 2013$ and 2013/2014. On average, in year $2012 / 2013$, the annual production of seedlings in the Cooperatives surveyed was about 15,000 per Society (Figure 4). The trend increased to an average of 70,000 seedlings in year $2015 / 2016$. This translated into $367 \%$ increase in production of seedlings. There was significant increase $(P<0.05)$ in seedlings produced in years $2014 / 15,2015 / 2016$ and $2016 / 17$ since the project started when compared to years 2012/13 and 2013/14 (Figure 4). In year 2016/2017, there was a decrease in production of seedlings. This was attributed to seedlings that spilled over from the previous year, an indication that Cooperatives were able to meet the demand of the seedlings by the farmers.

The sale of seedlings by the Cooperatives to the farmers significantly improved the source of revenue generation by the cooperatives thus improving their capital base. The mean annual revenue generated per Society rose from about Kshs. 200,000 in year 2012/2013 to Kshs. $1,000,000$ in year 2016/2017 (Figure 5). This reflected a $400 \%$ increase in revenue generation. The generated revenue helped the Cooperatives to address the financial constraints they faced such as hiring of nursery casual workers, procuring of inputs for the nursery and meeting the administrative costs.

\section{Membership of FCS}

The members affiliated to a Cooperative Society are important as they jointly contribute in meeting the administrative costs of running the society. The Cooperatives with few members faces high costs of administratively running them and vice versa. Increase in membership is importatant as it minimize the running costs of the Cooperative society. Through the PPP support, the Cooperatives registered an increase in mean number of members per society (Figure 6). On average, members significantly increased by $15 \%$ from 2444 in year 2013 to 2807 by year 2017 per Cooperative. The increase of the members was attributed to new coffee farmers joining the coffee farming, an indication that 


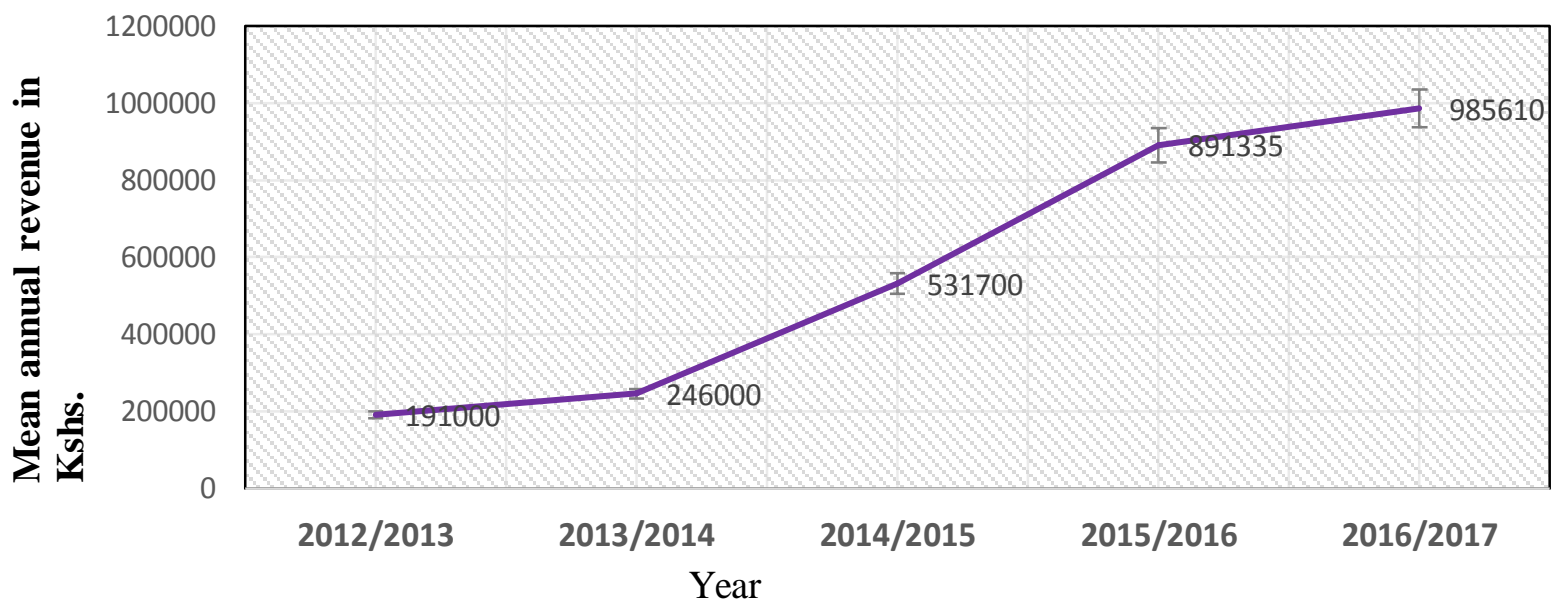

Figure 5. Mean annual revenue (Kshs.) from sale of seedlings per FCS.

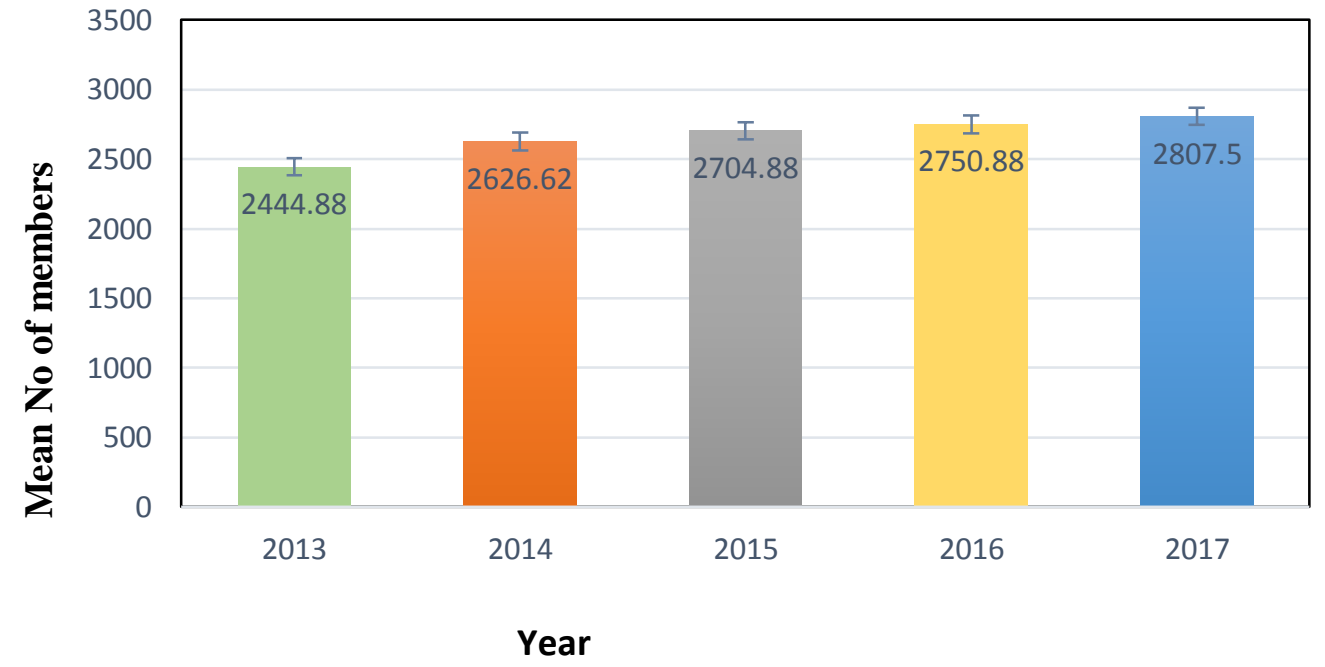

Figure 6. Mean total membership.

coffee business had become an attractive investiment.

\section{Coffee cherry delivered to cooperatives}

Volumes of cherries delivered to a Cooperative among other factors, determine its income from coffee sales. The more the sales the more the income and vice versa. The cherry delivered can be realized with increased coffee acreage, productivity and good agronomic practices. The members increase in the Cooperatives was associated with increased coffee cherry delivered. In year 2012/13 the mean cherry delivered was $228,452 \mathrm{~kg}$ per Cooperative. This increased to $285,952 \mathrm{~kg}$ in year $2016 / 17$ reflecting an increase of $25 \%$ (Figure 7). The increase was attributed to seedlings planted by old and news members from year 2014/2015 which started producing coffee in year 2016/2017. A decline observed in year 2015/16 was as a result of a prolonged drought that affected the overall production.

\section{Creation of employment opportunities}

The financial gains by the Cooperatives translated into jobs creation to the local communities as indicated by the respondents. The employment opportunities created included the temporary workers engaged to provide labour to the coffee nurseries. On average, each Cooperative engaged nine (9) employees.

\section{CONCLUSION}

The support of the Cooperatives through Public Private Partnerships' model impacted on improving the role of the Cooperatives that included the training of staff, revenue generation, cherry delivered and membership to 


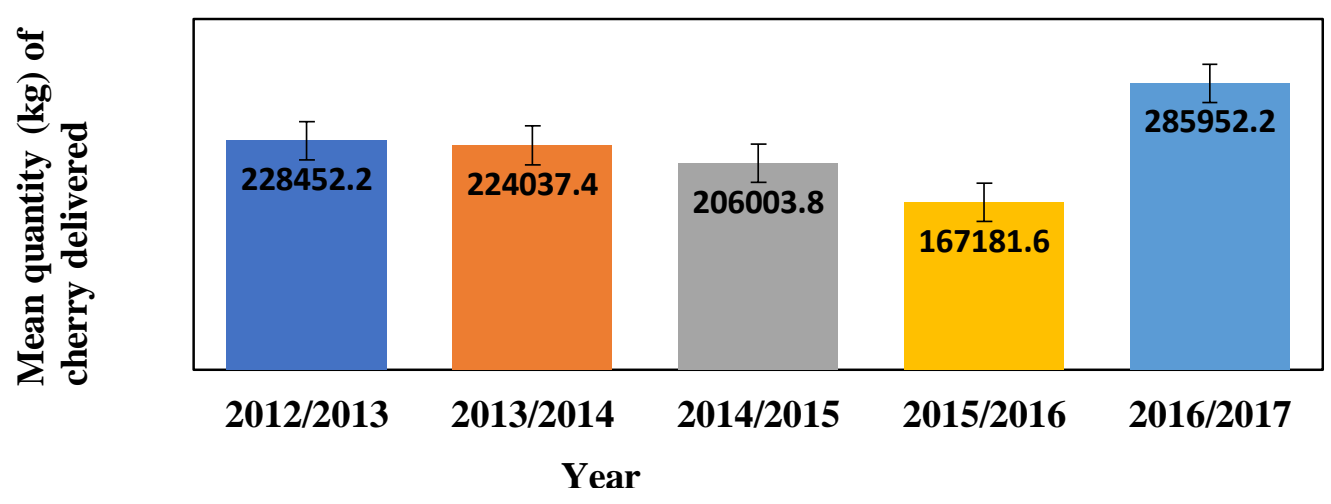

Figure 7. Mean quantity $(\mathrm{kg})$ of cherry delivered per FCS.

the Cooperatives. This resulted into promoting and improving production of coffee leading to improved farmers' livelihood and food security. It is proposed this kind of model under coffee enterprise, can be replicated on other enterprises to improve the livelihood and food security of the rural community.

\section{ACKNOWLEDGEMENTS}

We wish to thank the European Union (EU) and the Government of Kenya (GoK) for financing this project. Our acknowledgement is also to the County Governments and KALRO for their support during the project implementation.

\section{REFERENCES}

Aksoy MA (2012). African agricultural reforms: The role of consensus andinstitutions. Washington, D.C: World Bank.

Akuma E (2018). Coffee marketing, regulation and policy. The proceedings of the $3^{\text {rd }}$ National Coffee Conference and Trade Fair, Nairobi, Kenya. pp. 8-12.

Ellis CW (2005). Management skills for new managers. New York: AMACOM.

Fair-trade and Coffee (2012). Commodity briefing. Fairtrade Foundation pp. 1-25. www.fairtrde.org.uk.

International Cooperative Alliance (2007). What is a cooperative? http://www.ica.coop/coop/index.html.
International Coffee Organization (2019). Coffee production and marketing in Kenya (Online). Available from https://wwww.iconairobimeeting.com/wwww.www.afa.go.ke.

Kamau CN (2014). Factors influencing performance of coffee Cooperatives in Kangema constituency, Murang'a County, Kenya. Master of Arts in Project Planning and Management. Unversity of Nairobi. Kenya (Online). Available from https://hdl.handle.net/11295/74299.

Kenya Coffee Traders Association (2015). The Current Coffee Marketing System in Kenya. Kenya Coffee Traders Association (K.C.T.A.): pp. 1-27.

Kimemia JK (2018). The Kenya Coffee Platform. The proceedings of the $3^{\text {rd }}$ National Coffee Conference and Trade Fair, Nairobi, Kenya. pp. 13-19.

Mazzafera P (2012). Which Is the By-Product: Caffeine or Decaf Coffee? Food Energy Secur. 1(1):70-75.

Ministry of Agriculture and Animal Resources (2004). Plan Stratégique pour la Transformation de l'Agriculture au Rwanda (PSTA), Republic of Rwanda, Kigali.

United States Agency for International Development (2010). Kenya Coffee Industry Value Chain Analysis. Profiling the actors, their interactions, costs, constraints and opportunities. United States Agency for International Development (USAID), pp.1-20.

Van Der Vossen H, Walyaro D (2009). Additional evidence for oligogenic inheritance of durable host resistance to coffee berry disease (Colletotrichum kahawae) in Arabica coffee (Coffea arabica L.). Euphytica, 165(1):105-111.

Yuka K (2007). New role of Cooperatives in Ethiopia: the case of Ethiopian coffee farmers' cooperatives. African Study Monographs, Suppl.35: 87-108, Institute of Developing Economies, JETRO.

http://www.sciencewebpublishing.net/jacr 